\title{
Proportion of influenza cases in severe acute respiratory illness in Indonesia during 2008-2009
}

\author{
Ririn Ramadhany, ${ }^{1}$ Vivi Setiawaty, ${ }^{1}$ Holy A. Wibowo, ${ }^{1}$ Dewi Lokida ${ }^{2}$ \\ ${ }^{1}$ Center for Biomedical and Pharmaceutical Research and Development, National Institute of Health Research and Development, \\ Ministry of Health, Indonesia \\ ${ }^{2}$ Tangerang Hospital, Indonesia
}

\begin{abstract}
Abstrak
Tujuan: Mengetahui proporsi kasus SARI yang disebabkan oleh virus influenza. Metode yang digunakan untuk mendeteksi keberadaan virus influenza adalah metode Reverse Transkriptase - Polymerase Chain Reaction (RT-PCR).

Metode: Usap tenggorokyang diambil dari pasien yang memiliki simptom mengarah ke SARI di ekstrak untukmemperoleh RNA, kemudian diamplifikasi menggunakan 5 pasang primer dan probe (influenza A, Influenza B, A/H1N1, A/H3N2 dan A/H5N1) dengan metode real-time RT-PCR.

Hasil: Dari 549 sampel diketahui bahwa 6\% pasien SARI disebabkan oleh virus Influenza, dan 4\% disebabkan oleh virus Influenza A, 2\% disebabkan oleh virus Influenza B. Virus influenza A yang paling banyak menyebabkan SARI adalah virus A/H3N2. Sedangkan 94\% dari keseluruhan sampel SARI yang diterima menunjukan hasil negatif terhadap Influenza.

Kesimpulan: Sebagian besar kasus SARI tidak disebabkan oleh virus influenza. Virus influenza A yang paling sering menyebabkan SARI adalah A/H3N2. Kondisi bahwa Kasus flu burung A/H5N1 sudah pernah diidentifikasi di Indonesia serta penyebaran virus baru influenza A/H1N1 pada tahun 2009 meningkatkan kembali pentingnya survelians SARI. (Med J Indones 2010; 19:264-7)
\end{abstract}

\begin{abstract}
Aim: To access the proportion of Influenza which caused SARI cases

Methods: From April 2008 until March 2009, 549 samples of nasal and throat swabs were collected from SARI patients from eight hospitals in eight provinces in Indonesia. The samples were analyzed for Influenza by real-time RT-PCR method using several specific primers for influenza A (A/H1N1, A/H3N2 and A/H5N1) and Influenza B. The sequence of these primers was provided by CDC, Atlanta.

Results: We found 516 (94\%) of the specimens testing results were not influenza A or B viruses. There was 21 (4\%) cases caused by influenza A and 12 (2\%) caused by influenza B. From the influenza A cases, one case of SARI was caused by A/H1N1, two cases were A/H5N1, 17 cases were A/H3N2 and one case was unsubtypeable Influenza A.

Conclusion: The majority of SARI cases were not caused by influenza viruses. From this surveillance the most common influenza A related to SARI is A/H3N2. Facts of the avian influenza virus A/H5N1 cases have been found in Indonesia and the spread of novel virus influenza A/H1N1 in 2009 raised our concern about the importance of SARI surveillance. (Med J Indones 2010; 19:264-7)
\end{abstract}

Key words: influenza, severe acute respiratory illness

The spread of avian influenza virus A/H5N1 in 2003 and novel virus influenza $\mathrm{A} / \mathrm{H} 1 \mathrm{~N} 1$ in 2009 has raised our concern about influenza pandemic. Influenza is one of major problems which cause respiratory infections. At least 3 influenza pandemics have taken place since 1918 all around the world until recently. First pandemic occurred in Spain (then called as Spanish flu) caused by H1N1 virus in 1918. Then in 1957 Asian flu (H2N2) pandemic followed and Hong Kong flu (H3N2) in 1968. ${ }^{1}$ Another concern is about the possibility of new pandemic caused by H5N1. The first outbreak of H5N1 in human occurs in Hong Kong (1997), at least 18 people confirmed and Correspondence email to: ririn_ramadhany@yahoo.com
6 have been fatal. ${ }^{2}$ In Indonesia, from 2005 until January 2009, there are 141 H5N1 confirmed cases, in which 115 have been fatal. ${ }^{3}$

Influenza viruses, which are classified as a family Orthomyxoviridae, consist of eight segments single stranded RNA whichencode 10proteins. Those 10 proteins are PB1 (polymerase basic 1), PB2, PA (polymerase acidic), HA (hemagglutinin), NP (nucleocapsid), NA (neuraminidase), matrix proteins M1 and M2, nonstructural protein NS1 and NS24. Matrix protein, HA and NA have major role in Influenza classification. Influenza virus was 
classified into 3 types, i.e. Influenza A, B and C based on its matrix protein. Influenza $\mathrm{B}$ and $\mathrm{C}$ viruses only infect animal and are restricted to human, while A viruses can infect both animal (especially in avian, pigs and horses) and human. ${ }^{4}$ The subtypes of Influenza are determined by it's HA and NA glycoprotein surface antigens. There are at least 16 subtypes of HA in Influenza A (H1 to H16) which associates with 9 types of Neuraminidase (N1 - N9). ${ }^{5}$

In general, the symptoms of Influenza A range from asymptomatic into respiratory illnesses with systemic complication. The severity of influenza viruses is also related to the viruses subtype, almost H3N2 subtypes are associated to lower respiratory symptoms. ${ }^{6}$ Moreover, the infections of H3N2 cause more severe infections than H1N1 subtypes and Influenza B, in terms of fever, leucopenia, and C-reactive protein. ${ }^{7}$

Severe acute respiratory illness (SARI) is an acute infection occurs in respiratory systems especially in alveoli or interstitial tissue in human lungs. The symptoms which lead to SARI are fever, cough, sore throat, shortness of breath or difficulty of breathing and requiring hospitalization. Bacteria responsible for acute respiratory infections in human, especially children, are Streptococcus pneumoniae, Haemophilus influenzae type B, Staphylococcus aureus, and other bacterial species. Furthermore, viruses also can cause acute respiratory infections, such as Respiratory Syncytial Virus (RSV), Measles Virus, Human Parainfluenza Viruses type 1, 2, and 3 (PIV-1, PIV-2 and PIV-3), Influenza Virus and Varicella Virus. ${ }^{3}$ To monitor severe respiratory infections in Indonesia, the National Institute of Health Research and Development (NIHRD) conducted laboratory based surveillance for Severe Acute Respiratory Infection (SARI) since 2008.

In this study, the proportion of influenza which causes severe acute resporatory illness will be accessed. In other words, this study can be used for early warning of influenza outbreak and for Influenza Pandemic preparedness.

\section{METHODS}

Samples which were used in this study are throat swab (TS) from patients who had symptoms of severe acute respiratory illness from Adam Malik Hospital (North Sumatera), M. Hoesin Hospital (South Sumatera), Kariadi Hospital (Center of Java), Hasan Sadikin Hospital (West Java), Pasarebo Hospital (DKI Jakarta), Tangerang Hospital (Tangerang), Johanes Hospital (East Nusa Tenggara), and Kanujoso Djati Hospital (East Kalimantan). From the 8 Indonesian hospitals, 549 samples were consecutively collected from April 2008 until March 2009 and sent to NIHRD laboratory to be analyzed. Throat swab samples were extracted by using QiAmp RNA viral mini Kit (Qiagen) to obtain the RNA virus.

Furthermore, the RNA of Influenza virus was analyzed by using realtime /quantitative Reverse Transcriptase Polymerase Chain Reaction (qRT-PCR) methods. Realtime PCR used fluorescence as indicator. Data were collected during amplification. If target DNA is present, the fluorescence increase and reactions were recognized as positive by computer algorithms that analyze the change in fluorescence with cycle number. How soon this rise occurs depends on the initial amount of target DNA 8.In this study, 5 sets of primers and probes were used to detect Influenza A, Influenza B, A/H1N1, A/ $\mathrm{H} 3 \mathrm{~N} 2$ and $\mathrm{A} / \mathrm{H} 5 \mathrm{~N} 1$. These primer and probe sequences were obtained from US CDC, Atlanta (unpublished). First, the RNA samples were screened for Influenza A and Influenza B. If it was positive for Influenza A, then the RNA samples were subtyped by using A/H1N1, A/ H3N2 and A/H5N1. RT-PCR was performed by using Thermal Cycler IQ5, Biorad and Superscript III qRTPCR with Platinum Taq Polymerase (Invitrogen). Five microliters extracted RNA were amplified by following temperature program: reverse transcriptase activation in $50^{\circ} \mathrm{C}$ for 30 minutes, continued by taq inhibitor activation in $95^{\circ} \mathrm{C}$ for 2 minutes. PCR cycles were repeated 45 times, denaturation was performed in $95^{\circ} \mathrm{C}$ for 5 seconds and annealling in $55^{\circ} \mathrm{C}$ for 30 seconds.

\section{RESULTS}

From RT-PCR results of Influenza A and Influenza B, it was shown that only $4 \%$ of 549 SARI samples showed positive for Influenza A, and about $2 \%$ positive for Influenza B while $94 \%$ of the samples showed negative for both Influenza A and Influenza B. It indicates that there were other agents beside Influenza which can cause severe pneumonia in human respiratory systems (Graph 1).

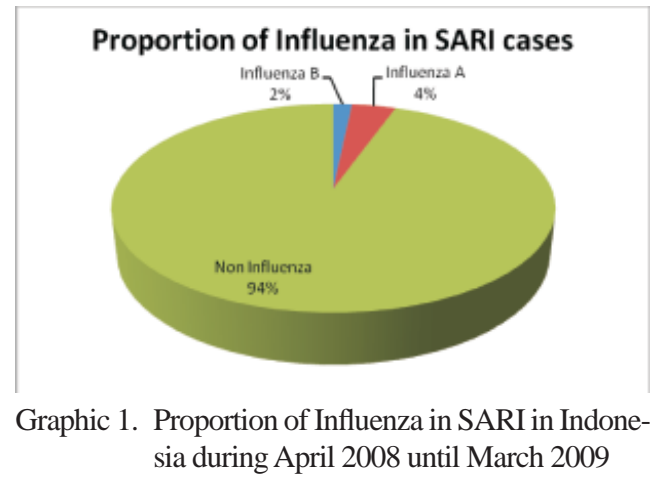


To obtain more detailed information about Influenza A which caused severe illnesses, we analyzed the RNA using other 3 sets of primer, each set for A/ $\mathrm{H} 1 \mathrm{~N} 1, \mathrm{~A} / \mathrm{H} 3 \mathrm{~N} 2$ and $\mathrm{A} / \mathrm{H} 5 \mathrm{~N} 1$. The primers used in this assay were specifics for Hemagglutinin gene (HA) of Influenza. From graphic 2, proportion of Influenza A virus in SARI, it was known that Influenza $\mathrm{A} / \mathrm{H} 1 \mathrm{~N} 1$, $\mathrm{A} / \mathrm{H} 3 \mathrm{~N} 2$, and $\mathrm{A} / \mathrm{H} 5 \mathrm{~N} 1$ can be a trigger which leads to severe pneumonia. The results of RT-PCR revealed that one case of SARI was caused by A/H1N1 strain, two cases were caused by A/H5N1 strain and one case was unsubtypeable Influenza A. The most common influenza A which lead to severe pneumonia is A/H3N2. There were about 17 of SARI cases were confirmed as positive A/H3N2.

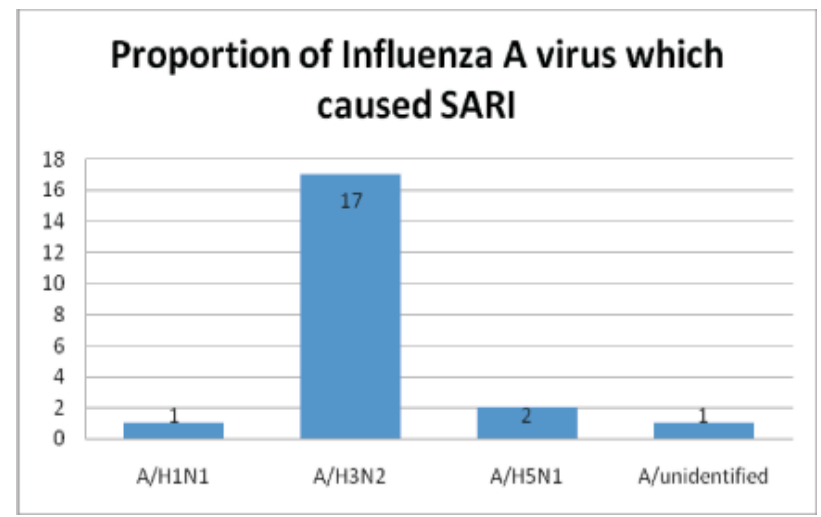

Graphic 2.Proportion of Influenza A virus which caused SARI in Indonesia during April 2008 until March 2009

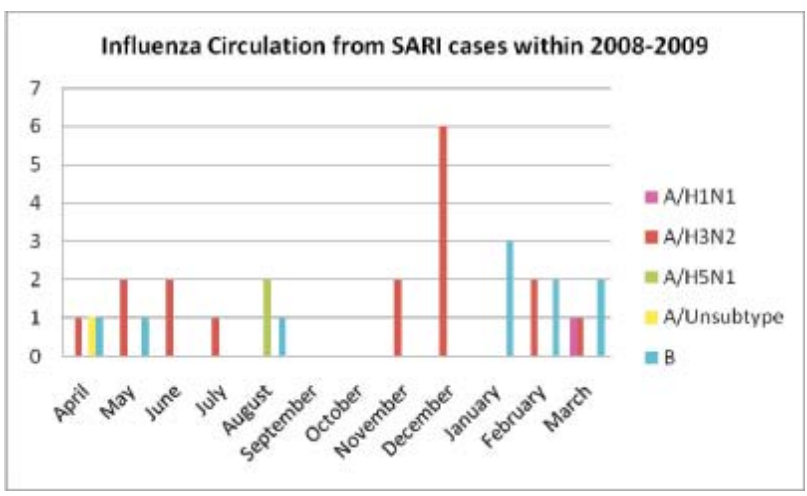

Graphic 3. Circulation of Influenza virus in SARI cases in Indonesia from 2008 until 2009

Seasonal influenza (A/H1N1, A/H3N2 and influenza B) usually occur during rainy season. But from the collected data, it was shown that influenza causing SARI circulated during the year, except in September and October (Graphic 3).

\section{DISCUSSION}

RNA from those samples were tested for Influenza A and Influenza B by real-time RT-PCR. Primer and probe for Influenza A and Influenza B used in this study were specific for gene $\mathrm{M}$ of Influenza. Gene $\mathrm{M}$ is a conserved gene of influenza which used to determine the type of Influenza virus. Influenza A and Influenza B have similar epidemiological characteristics which can cause morbidity and mortality in population. Influenza B has less possibility to produce influenza pandemic because it's inherent antigenic. In general, Influenza B produces lower community-wide infection than Influenza A. ${ }^{4}$

Influenza A was commonly spread among human and animal, while Influenza B only infect human and can not infect animal. Influenza A has a wide range of symptom, starting from mild or asymptomatic respiratory illness to severe pneumonia or even death. In SARI cases, the symptom of infections leads to severe pneumonia and ought to hospitalization. Majority of SARI cases were not caused by influenza virus (about 94\%), only 6\% of SARI cases caused by Influenza virus, which are $4 \%$ caused by influenza A and $2 \%$ caused by influenza B. It is shown that most common influenza A causing SARI in Indonesia during April 2008 until March 2009 was A/H3N2 strain. The virus type correlate with severity, it was known that Influenza A/H3N2 is associated with higher frequencies of lower respiratory symptoms, pulmonary function changes, and physician visits than Influenza A/H1N1. ${ }^{6}$ Study about Influenza symptom which held by Kaji,et.al. in 2003 in Japan ${ }^{7}$ showed comparison between the symptom of influenza A/H3N2, A/H1N1 and Influenza B. Based on their research, Influenza A/H3N2 infection was more severe than strain A/H1N1 and Influenza B. It also known that the rate of pneumonia and influenza hospitalization of Influenza A/H3N2 was higher than influenza A/H1N1 or influenza B. ${ }^{9}$ Fever was much greater in the patients positive for A/H3N2 than in the A H1N1 or B groups, the body temperature was $38.6 \pm 0.46^{\circ} \mathrm{C}$. However, severity of infection was not only caused by viruses' type but also can be associated with several factors such as the presence of circulating influenza antibody, age and smoking behavior. Infection rates on people with lower titer antibody was higher that those who has higher titers of antibody. Influenza infection known to be high among children and teenagers but mortality is higher in elderly population. Moreover, illness severity and sickness due to influenza are also higher among smokers. ${ }^{4}$ 
The peak of Influenza A/H3N2 circulation in Indonesia, which was found in higher number in SARI cases, occurred in December. While Influenza B found in constant number in several months such as in April, May, August, and January until March. Influenza A/unsubtypeable and A/ H1N1 found very minor in SARI cases, there only one case of each. Influenza $\mathrm{A}$ /unsubtypeable occurred in April 2008, while Influenza A/H1N1 occurred in March 2009. It is more likely that the peak of influenza virus's circulation in Indonesia occurs in rainy season, especially for influenza A/H3N2. The circulation of Influenza virus during April 2008 until March 2009 was similar to what has been observed in Influenza Surveillance in 1999 until 2003. Based on Influenza Surveillance in Indonesia in 1999 until 2003, it was known that peak prevalence of Influenza A/H1N1, A/H3N2 and influenza B occurred during rainy season 10 .

\section{Acknowledgments}

We would like to thank Center for Disease Control and Prevention (CDC), Atlanta, Georgia, USA and WHO for Indonesia for their financial support for these studies. We really appreciate the help for providing the primers/ probe and antigens. Special thanks went to Mr. Frank Mahoney, PhD, CDC Atlanta, Georgia, USA and Dr. Graham Tallis, WHO for Indonesia. We thank to our many colleagues at the Virology Laboratory of National Institute of Health Research and Development, Ministry of Health, Jakarta, Indonesia and SARI sentinel hospitals for their contributions to our laboratory investigations.

\section{REFERENCES}

1. Cox NJ, Subbarao K. Global Epidemiology of Influenza: Past and Present. Ann Rev of Med. 2000; 51: 407-21

2. Chan PK. Outbreak of avian influenzaA (H5N1) virus infection in Hong Kong 1997. Clin Infect Dis. 2002; 34 Suppl 2: S58-64

3. World Health Organization (WHO). 2009. Avian Influenza - situation in Indonesia ( updated 22 January 2009 cited 8 June 2009) Available from : http://www.who.int/vaccine_ research/diseases/ari/en/index1.html.

4. Nicholson KG, Webster RG, Hay AJ. Text Book of Influenza. Blackwell Science Ltd. London. 1998. p:194

5. Peiris JSM, De Jong MD, Guan Y. Avian Influenza Virus (H5N1): a Threat to Human Health. Clin Microbiol. 2007; 20(2): 243-67

6. Hayden FG, Palese P. Influenza Virus. In: Richman, D.D., R.J. Whitley, and F.G. Hayden. Clinical Virology 2nd ed. ASM Press. Washington. 2002. p:904

7. Kaji M, Watanabe A, Aizawa H. Differences in clinical features between influenza A H1N1, A H3N2, and B in adult patients. Respirology. 2003; 8(2):231-3

8. Persing DH, Tenover FC, Versalovic J, Tang YW, Unger ER, Relman DA, et al. Molecular Microbiology. Diagnostic Principles and Practice. ASM Press. Washington. 2004. pp : 71-3

9. Simonsen L, Fukuda K, Schonberger LB, Cox NJ. The Impact of Influenza Epidemics on Hospitalizations. J Inf Dis. 2000; 181:831-7

10. Beckett CG, Kosasih H, Ma'roef C, Listiyaningsih E, Elyazar IR, Wuryadi S, et al. 2004. Influenza Surveillance in Indonesia : 1999-2003. Clin Infect Dis. 2004. 39:443-9 